\title{
DEVELOPMENT OF FERMENTED BEVERAGES BASED ON ACID WHEY
}

\section{OPRACOWANIE NAPOJÓW FERMENTOWANYCH NA BAZIE SERWATKI KWASOWEJ}

Department of Dairy Technology and Food Storage, West Pomeranian University of Technology, Szczecin, Poland

\begin{abstract}
Streszczenie. Serwatka kwasowa jest cennym surowcem uzyskiwanym podczas produkcji serów twarogowych oraz kazeiny kwasowej. Pomimo znacznego rozwoju technik przetwórstwa serwatki wykorzystanie serwatki kwasowej, ze względu na jej niskie $\mathrm{pH}$, nadal pozostaje wyzwaniem, zwłaszcza dla małych zakładów mleczarskich. Celem pracy było opracowanie i ocena fermentowanych napojów na bazie serwatki kwasowej z udziałem kultur jogurtowych. W celu zwiększenia zawartości kazeiny i uzyskania produktu o cechach jakościowych zbliżonych do fermentowanych napojów mlecznych serwatkę połączono z mlekiem, niesłodzonym mlekiem skondensowanym lub $\mathrm{z}$ odtłuszczonym mlekiem $\mathrm{w}$ proszku. Ponadto napoje wzbogacano w prebiotyki (inulinę i oligofruktozę) albo w białko serwatkowe, dodając koncentraty WPC (whey protein concentrates). Ocena napojów obejmowała pomiar kwasowości i analizę sensoryczną. W pracy badano również wpływ pasteryzacji serwatki na jakość napojów. Na podstawie otrzymanych rezultatów wybrano najlepsze surowce i dodatki do produkcji napojów na bazie serwatki kwasowej. Wyniki pozwoliły opracować kilka wariantów napoju o pożądanych właściwościach. Stwierdzono, że aby otrzymać produkt o dobrych właściwościach sensorycznych, dodatek mleka musi wynosić co najmniej $50 \%$. Najbardziej odpowiednią obróbką cieplną serwatki była pasteryzacja w temperaturze $72^{\circ} \mathrm{C}$ przez 10 minut. Uzyskane wyniki wskazują, że serwatka kwasowa może być wykorzystana jako surowiec do produkcji akceptowanych sensorycznie napojów fermentowanych. Praca przedstawia nową metodę bezpośredniego wykorzystania serwatki kwasowej, która może stanowić atrakcyjną propozycję dla przemysłu mleczarskiego.
\end{abstract}

Key words: acid whey, fermented beverages, yogurt bacteria, WPC, prebiotics.

Słowa kluczowe: serwatka kwasowa, napoje fermentowane, kultury jogurtowe, WPC, prebiotyki.

\section{INTRODUCTION}

Whey is a by-product remaining after separation of curd in cheese making. According to method of casein coagulation, two main types of whey are produced: acid whey, obtained during the production of acid-coagulated cheese such as tvorog cheese, and rennet whey, from the manufacture of rennet-coagulated cheese. The volume of whey amounts about 85-90\% of milk used in the production (Pescuma et al. 2010). During cheese manufacturing, approximately $50 \%$ of milk solids go to whey. The average composition of whey is $93.3 \%$ of

Corresponding author - Adres do korespondencji: Katarzyna Skryplonek, Department of Dairy Technology and Food Storage, West Pomeranian University of Technology, Szczecin, Papieża Pawła VI 3, 71-459 Szczecin, Poland, e-mail: katarzyna.skryplonek@zut.edu.pl 
water, $5.1 \%$ of lactose, $0.8 \%$ of protein and $0.2 \%$ of fat. Whey proteins are especially valuable ingredients with a lot of health benefits. Moreover whey is rich in water-soluble vitamins, mainly from group B and minerals like calcium and phosphorus (FAO 2013). Acid whey contains considerable amounts of lactic acid, thus is characterized with $\mathrm{pH}<5$. It also has lower amounts of protein and higher amount of minerals in comparison with rennet whey. These factors causes that acid whey is less suitable for processing than rennet whey (Dajnowiec and Zander 2013). In 2010 global whey production amounted 165 million tonnes, from which about 68\% was obtained in Europe (Darade and Ghodake 2012, Pereira et al. 2015). According to Sparks (2015), production of whey in Poland in year 2014 ranged 1.4 million tonnes. Moreover the recent observations shows, that global cheese and consequently whey production growths for approximately $2 \%$ per year (Dajnowiec and Zander 2013). Global market of whey and whey formulations is estimated for a value of app. 6.3×109 EUR (Pereira et al. 2015). In the view of growing production and high nutritional value of whey ingredients, this raw material finds more and more applications in variety of food products. Although food industry reaches mainly for formulations based on whey like whey proteins isolates or modified whey proteins.

The direct use of whey, especially acid whey to obtain valuable food product is not common. The fluid nature of whey implicates that it can be reasonable raw-material for beverage production. Beneficial nutritional composition contribute to the development of whey beverages, which is connected with the consumers' demand of innovative products made of natural ingredients and possessed high nutritional quality and health promoting properties (Chavan et al. 2015). Analyzing the literature we can find numerous examples of whey-based beverages, which can be divided into few main groups including: unfermented and fermented beverages, milk-type beverages, probiotic beverages, refreshing soft drinks, alcoholic beverages, diet beverages, high-protein sport drinks, beverages for direct consumption and powder beverages (Jeličić et al. 2008; Chavan et al. 2015). However the vast majority of these products are made from rennet whey. The use of acid whey is limited mainly to mixes with fruit juices (Sirohi et al. 2005; Sakhale et al. 2012; Dhamsaniya and Varshney 2013).

The aim of the study was to design a new high quality, fermented milk-type beverage based on acid whey obtained during industrial acid cheese production. The study focused on the choice of the most appropriate type of acid whey as well as selection other components and production parameters in order to obtain a product of the highest quality, which would meet consumer demands. Proper selection of the composition and production parameters of whey-based fermented beverages aimed to receive an innovative product combining the nutritional value of whey and fermented milk. Lactic acid fermentation of whey can significantly improve its nutritional properties by reduction the lactose content, reduction in allergenicity of proteins through their partial hydrolysis, increase the content of bioactive peptides and improvement of the sensory properties due to flavour compounds produced by lactic acid bacteria (Gallardo-Escamilla et al. 2007; Pescuma et al. 2010).

\section{MATERIAL AND METHODS}

The main raw material for beverages production was acid whey delivered from dairy plant located in north-west Poland. The whey was obtained during semi-fat acid tvorog production. It was transported and stored under refrigeration and beverages were manufactured in 
laboratory conditions. In order to fully characterize the whey as a main raw material, the stages of acid tvorog cheese and consequently whey production are presented. Semi-fat acid tvorog was manufactured from pasteurized milk with $0.8 \%$ fat content. Milk was fortified with calcium chloride $\left(0.04 \mathrm{~g} \cdot \mathrm{L}^{-1}\right)$ and DVS (Direct Vat Inoculation) starter culture of lactic acid bacteria $\left(0.025 \mathrm{~g} \cdot \mathrm{L}^{-1}\right)$. The coagulation was performed in temp. $22-30^{\circ} \mathrm{C}$ for $12-18 \mathrm{~h}$. Subsequently, the curd was cut, heated and stirred and whey was drained. Then the curd was rinsed, moulded, pressed and packaged. Auxiliary raw materials and additives used in the experimental beverages production are presented in Table. 1.

Table 1. Auxiliary raw materials and additives used in whey-based beverages production Tabela 1. Surowce pomocnicze i dodatki stosowane do produkcji napojów na bazie serwatki

\begin{tabular}{lll}
\multicolumn{1}{c}{$\begin{array}{c}\text { Type of raw material or additive } \\
\text { Rodzaj surowca lub dodatku }\end{array}$} & \multicolumn{1}{c}{$\begin{array}{c}\text { Manufacturer } \\
\text { Producent }\end{array}$} & $\begin{array}{c}\text { Additional information } \\
\text { Dodatkowe informacje }\end{array}$ \\
\hline $\begin{array}{l}\text { UHT milk } \\
\text { Mleko UHT, „Paturages” }\end{array}$ & OSM WART-MILK, Poland & $3.2 \%$ fat - tłuszcz \\
\hline $\begin{array}{l}\text { UHT milk } \\
\text { Mleko UHT, „Paturages” }\end{array}$ & OSM WART-MILK, Poland & $0 \%$ fat - tłuszcz \\
\hline $\begin{array}{l}\text { Unsweetened condensed milk (UCM ) } \\
\text { Niesłodzone mleko kondensowane }\end{array}$ & SM Gostyń, Poland & $\begin{array}{l}7.5 \% \text { fat - tłuszcz, 17.5\% non-fat } \\
\text { solids - sucha masa beztłuszczowa }\end{array}$ \\
\hline $\begin{array}{l}\text { Skimmed milk powder (SMP) } \\
\text { Odtłuszczone mleko w proszku }\end{array}$ & SM Gostyń, Poland & $0.2 \%$ fat - tłuszcz \\
\hline $\begin{array}{l}\text { Whey protein concentrate } \\
\text { Koncentrat białek serwatkowych } \\
\text { WPC 35 }\end{array}$ & SM Spomlek, Poland & $\sim 35 \%$ protein - białko \\
\hline $\begin{array}{l}\text { Whey protein concentrate } \\
\text { Koncentrat białek serwatkowych, } \\
\text { WPC 80 }\end{array}$ & SM Spomlek, Poland & $\sim 80 \%$ protein - białko \\
\hline $\begin{array}{l}\text { Inulin } \\
\text { Inulina ORAFTI GR }\end{array}$ & BENEO, Belgium & prebiotic - prebiotyk \\
\hline $\begin{array}{l}\text { Oligofructose } \\
\text { Oligofruktoza ORAFTI P95 }\end{array}$ & BENEO, Belgium & prebiotic - prebiotyk \\
\hline
\end{tabular}

The fermentation process was conducted with the use of commercial culture of yogurt bacteria Streptococcus thermophilus and Lactobacillus delbruecki ssp. bulgaricus (YO-MIX, Danisco, Denmark). The DVS freeze-dried culture was previously diluted in sterile skimmed milk, heated to $42 \pm 1^{\circ} \mathrm{C}$ and added to the mixture in amount $0.06 \mathrm{~g} \cdot \mathrm{L}^{-1}$.

In order to design the beverages with optimal sensorial and physicochemical properties, a wide range of experiments were conducted, in which the composition of beverages and pasteurization parameters were taken into account. The work was set to obtain product with sensory properties similar to popular among consumers fermented dairy drinks. It required the enrichment of whey with auxiliary raw materials and additives which role was to increase solids content and consistency of the product. In order to increase content of casein, protein which play a pivotal role in shaping the texture of fermented beverages, whey was combined with uncondensed milk, condensed unsweetened milk and milk powder. Moreover, there was analyzed the possibility of using other thickening additives, which were whey protein concentrates and hydrocolloids inulin and oligofructose.

\section{Beverages from whey combined with skimmed milk powder (SMP)}

The development process started with preparing beverages containing only whey and beverages fortified with skimmed milk powder addition. In order to improve microbiological 
quality, whey was heated to temperature of $80^{\circ} \mathrm{C}$ for about 1 minute. This temperature is used in the high temperature pasteurisation of milk. Then 0,100 or $200 \mathrm{~g} \cdot \mathrm{L}^{-1}$ of SMP was added. The mixtures were cooled to $42 \pm 1{ }^{\circ} \mathrm{C}$ and inoculated with starter culture. Subsequently they were poured into PE-LD containers in a volume of approximately $50 \mathrm{~mL}$, tightly covered with aluminium foil and incubated at $42^{\circ} \mathrm{C}$ for 3-4 hours until the curd receiving. The beverages were cooled and stored at temp. $5 \pm 1^{\circ} \mathrm{C}$ overnight. Described production scheme was used also in further steps of work.

\section{Beverages from whey combined with milk}

SMP constituent a material which considerably increases the cost production. Thus in the subsequent step of beverages development the possibility of SMP replacement with uncondensed milk was tested. Quark whey, after heating to $80^{\circ} \mathrm{C}$, was combined with UHT milk with $3.2 \%$ fat content. The whey to milk proportions amounted $2: 1,1: 1$ and $1: 2$.

Inulin, oligofructose, WPC 35 and WPC 80 addition. Further variants of beverage were made from quark whey and UHT milk combined in a ratio of $2: 1$ and $1: 1$ enriched with 20 or $30 \mathrm{~g} \cdot \mathrm{L}^{-1}$ of inulin, oligofructose, WPC 35 or WPC 80 . The incorporation of additives followed after the step of heating the whey to a temperature of $80^{\circ} \mathrm{C}$.

Simultaneous addition of inulin, oligofructose and WPC. Further variants of beverages were manufactured from quark whey and milk combined in $1: 1$ ratio. In this step, the synergistic effect of prebiotics and whey protein concentrates on the product quality was assessed. Prebiotics inulin and oligofructose were added in amounts of $20 \mathrm{~g} \cdot \mathrm{L}^{-1}$, while whey protein concentrates WPC 35 and WPC 80 in quantities of 5 or $10 \mathrm{~g} \cdot \mathrm{L}^{-1}$.

\section{Beverages from whey combined with milk and SMP}

In order to improve textural characteristics of beverages made of acid tvorog whey and milk (1: 1), the mixture was enriched with 50 or $100 \mathrm{~g} \cdot \mathrm{L}^{-1} \mathrm{SMP}$ addition. The beverages were analyzed after 1 and 14 days of refrigerated storage.

\section{Beverages from whey combined with milk and condensed milk}

The study involved evaluation of unsweetened condensed milk usage. Pasteurized acid whey was combined with condensed milk in ratio $1: 1$ or the whey was mixed with condensed milk and uncondensed milk in ratio $2: 1: 1$. For comparison purposes, also beverage from whey and uncondensed milk (1:1) was prepared. The products did not contain any additives. The assessment was performer after 1 and 14 days of refrigerated storage.

\section{The effect of whey pasteurization on the quality of beverages}

Acid whey were pasteurized in batch method under the following conditions: treatment at $90^{\circ} \mathrm{C}$ for 5 minutes, $80^{\circ} \mathrm{C}$ for $5 \mathrm{~min}$ and $72^{\circ} \mathrm{C}$ for $10 \mathrm{~min}$. The whey pasteurized at of $80^{\circ} \mathrm{C}$ for $5 \mathrm{~min}$ and $a 2^{\circ} \mathrm{C}$ for $10 \mathrm{~min}$ as well as unpasteurized whey, were used for the production of beverages. The pasteurized or unpasteurized whey were combined with milk in a ratio of $1: 1$ and enriched with $20 \mathrm{~g} \cdot \mathrm{L}^{-1}$ oligofructose. To test the effect of pasteurization on the perishability of the products, the experimental beverages were stored at $5 \pm 1^{\circ} \mathrm{C}$ for 14 days. 


\section{Whey analyses}

Physicochemical analyses. The analysis of whey included determination of active acidity $(\mathrm{pH})$ - determined directly with the $\mathrm{pH}-$ meter (model CP-411, Elmetron, Poland); density using lactodensimeter; titratable acidity expressed in Soxhlet-Henkel degrees ( ${ }^{\circ} \mathrm{SH}$ ) determined by titration using $0.25 \mathrm{M} \mathrm{NaOH}$ solution; dry matter content determined by oven drying in $102^{\circ} \mathrm{C}$ (PN-A-86364:1996) and total protein content assessed by Kjeldahl method (PN-EN ISO 8968-1).

Microbiological analysis. Fresh and pasterurized semi-fat acid tvorog whey underwent the estimation of total count of bacteria. Decimal dilutions were made using peptone water (BTL, Poland). The analysis was carried out on Nutrient Agar Medium (BTL, Poland) after aerobic incubation in $30^{\circ} \mathrm{C}$ for $48 \mathrm{~h}$, according to the Polish Standard (PN-A-86034 : 1993) and medium manufacturer's instruction.

Sensory analysis. Descriptive evaluation was performed by panel of 6 trained evaluators and included the assessment of taste, flavour, appearance and consistency of whey. Conditions during the evaluation were in the accordance with guidelines given by Baryłko-Pikielna and Matuszewska (2009) and polish standard (PN-ISO 6658 : 1998).

\section{Beverages analyses}

Acidity. Physicochemical analyses of beverages included determination of titratable acidity and active acidity $(\mathrm{pH})$ as the main indicators of quality of fermented beverages. Measurements were carried out in a analogous manner as in the case of whey.

Sensory analysis. Similarly as in case of whey, the analysis was performed using descriptive method by panel of 6 trained persons. The evaluators assessed at first the flavour and appearance of beverages, then after gentle stirring with a spoon, the consistency, taste and mouthfeel of products were rated. The study focused on sensory evaluation, because high sensorial acceptability of food products is one of the crucial factors during new foodstuff development. Meeting the consumers' demands related with sensory properties is pivotal to achieve commercial success (Castro et al. 2013).

\section{Statistical analysis}

All analyses were done in triplicate and presented results are mean values. Furthermore, the results of the acidity analyses were subjected to statistical verification $(p=0.05)$. Standard deviation was calculated and two-way analysis of variance was performed. The software Microsoft Excel 2003 was applied.

\section{RESULTS AND DISCUSSION}

The physicochemical and sensory properties of acid whey after tvorog production are the results of the evaluation of 8 samples obtained during different days of production. $\mathrm{pH}$ value was $4.49 \pm 0.07$ and titratable acidity was $26.06 \pm 0.87^{\circ} \mathrm{SH}$. Dry matter content was $6.18 \pm 0.79 \%$ and fat content $0.1 \%$. Protein content amounted $1.02 \pm 0.15 \%$ and density of whey was $1.025 \pm 0.001 \mathrm{~g} \cdot \mathrm{cm}^{-3}$. Sensorial properties of whey were positively assessed by sensory panel. It possessed intensive and refreshing flavour, opaque appearance and light yellow-greenish colour. 


\section{Beverages with SMP}

Whey is considered as a good medium for growth of lactic acid bacteria. In number of studies whey was subjected to fermentation conducted by strains of yogurt bacteria (Kar and Misra 1999; Gallardo-Escamilla et al. 2007), or by yogurt bacteria combined with probiotics (Pescuma et al. 2008; Bulatović et al. 2014). Moreover, according to Magalhães et al. (2010), whey is appropriate environment for growth of kefir grains. In the study, the beverages were fermented in the temperature of $42 \pm 1^{\circ} \mathrm{C}$, which according to Kar and Misra (1999), is an optimal value for whey fermentation by strains of yogurt bacteria. In quoted study, the authors highlighted therapeutic value of fermented whey, which may facilitate the transit of viable yogurt bacteria to intestines. Benefits of using $S$. thermophilus and $L$. delbruecki ssp. bulgaricus for whey fermentation were pointed out also by Pescuma et al. (2008). They reported than due to partial hydrolysis of whey proteins like $\beta$-lactoglobulin, yogurt bacteria contribute to allergenicity reduction. Additionally, by releasing bioactive peptides with therapeutic properties like capacity to lower blood pressure or cholesterol content, health promoting value of whey is improved (Jędrychowski 1999). Other advantage of yogurt bacteria is connected with the fact, that during fermentation process they are able to release exopolysaccharides which may enhance textural properties of beverages (Zourari et al. 1992).

The fermentation of whey without any additives resulted in obtaining completely liquid product with properties similar to the untreated whey. This beverage had the highest acidity from all obtained in this stage samples (Table 2).

Table 2. Acidity of beverages from whey mixed with milk Tabela 2. Kwasowość napojów z serwatki połączonej z mlekiem

\begin{tabular}{lcc}
\multicolumn{1}{c}{ Whey and milk ratio } & & Acidity - Kwasowość \\
\cline { 2 - 3 } Stosunek serwatki do mleka & $\mathrm{pH}$ & titratable - miareczkowa [ $\left.{ }^{\circ} \mathrm{SH}\right]$ \\
\hline Whey-milk - Serwatka-mleko 2: 1 & 4.99 & $25.5 \pm 0.2$ \\
Whey-milk - Serwatka-mleko 1: 1 & 4.99 & $25.9 \pm 0.5$ \\
Whey-milk - Serwatka-mleko 1:2 & 4.76 & $31.2 \pm 0.4$ \\
\hline
\end{tabular}

Moreover due to totally liquid consistency, it wasn't considered as product similar to fermented milk drinks. The SMP addition resulted in distinctive decrease of $\mathrm{pH}$ and increase of titratable acidity, due to higher content of milk solids. Statistical analysis showed, that the effect of SMP addition on both $\mathrm{pH}$ and titratable acidity was significant $(\mathrm{p}=0.05)$. Milk proteins and minerals shape titratable acidity of product and their buffering capacity stabilize the $\mathrm{pH}$ value (Akalin et al. 2007; Marafon et al. 2011).

In case of sensorial properties, Beverages with 10\% SMP had very loose curd and syneresis was very intensive. Volume of spontaneously separated liquid phase exceeded half of the sample volume. Samples with $20 \%$ SMP had much better consistency. Curd had thicker structure and syneresis was minimal, although such considerable amount of SMP caused less distinct whey flavour.

\section{Beverages from whey combined with milk}

Previous studies have shown that the desirable sensory properties the beverages can be achieved through addition of $200 \mathrm{~g} / \mathrm{L}$ SMP. Further improvement can be reached by inulin or oligofructose implementation. In a subsequent step the whey was combined with uncondensed 
UHT milk in a ratio of $2: 1,1: 1$ and $1: 2$. The acidity of whey:milk beverages determined after 1 day of storage are shown in Table 2.

UHT milk was chosen, because as showed the results of preliminary study (data not included), beverages with this kind of milk was less vulnerable to liquid separation and syneresis occurring. This phenomenon may be presumably explained by a fact, that high temperature of heat treatment in UHT milk caused interactions of whey proteins with $\mathrm{K}$-casein on the surface of casein micelles. Those additional links in casein gel structure, may improve the stability of casein curd (Damin et al. 2009; Lee and Lucey 2010).

Results revealed that the beverages with the highest amount of milk in the mixture (whey : milk $1: 2)$ had significantly $(\mathrm{p}=0.05)$ higher both titratable and $\mathrm{pH}$ acidity in comparison with other products. It can be concluded that this variant constituent the best environment for the development of starter culture of bacteria. All samples had desirable and refreshing flavour, connecting characteristics of whey and fermented milk. The increase of milk addition improved consistency and decreased the level of separated liquid phase, though only variant with whey : milk ratio $1: 2$ was free of syneresis. However, in the view of the fact that the main component of this product is milk, it cannot be considered as beverage based on acid whey. Therefore, in further stages of the study, the actions to enhance the quality of variants with whey : milk ratio $2: 1$ and $1: 1$ have been taken. In order to eliminate syneresis and improve the consistency, analogously as products with SMP, the beverages were enriched with inulin and oligofructose as well as with WPC 35 and WPC 80 used in concentration of 20 and $30 \mathrm{~g} \cdot \mathrm{L}^{-1}$. The impact of whey:milk ratio and additives on beverages acidity is presented in Table. 3.

Table 3. Acidity of beverages from whey and milk with addition of inulin, oligofructose and WPC Tabela 3. Kwasowość napojów z serwatki i mleka z dodatkiem inuliny, oligofruktozy i WPC

\begin{tabular}{|c|c|c|c|}
\hline \multirow{2}{*}{$\begin{array}{l}\text { Whey and milk ratio } \\
\text { Stosunek serwatki } \\
\text { do mleka }\end{array}$} & \multirow{2}{*}{$\begin{array}{c}\text { Additives - Dodatki } \\
{[\mathrm{g} / \mathrm{L}]}\end{array}$} & \multicolumn{2}{|c|}{ Acidity - Kwasowość } \\
\hline & & $\mathrm{pH}$ & titratable - miareczkowa $\left[{ }^{\circ} \mathrm{SH}\right]$ \\
\hline \multirow{4}{*}{$\begin{array}{l}\text { Whey - Serwatka } \\
\text { Milk - Mleko } 2: 1\end{array}$} & inulin - inulina - 20 & 4.99 & $23.3 \pm 0.2$ \\
\hline & inulin - inulina - 30 & 4.98 & $22.9 \pm 0.5$ \\
\hline & oligofructose - oligofruktoza - 20 & 4.96 & $23.3 \pm 0.5$ \\
\hline & oligofructose - oligofruktoza - 30 & 4.97 & $23.3 \pm 0.2$ \\
\hline \multirow{4}{*}{$\begin{array}{l}\text { Whey - Serwatka } \\
\text { Milk - Mleko } 1: 1\end{array}$} & inulin - inulina -20 & 4.79 & $28.3 \pm 0.2$ \\
\hline & inulin - inulina - 30 & 4.79 & $28.5 \pm 0.2$ \\
\hline & oligofructose - oligofruktoza - 20 & 4.77 & $28.7 \pm 0.2$ \\
\hline & oligofructose - oligofruktoza - 30 & 4.77 & $28.4 \pm 0.0$ \\
\hline \multirow{4}{*}{$\begin{array}{l}\text { Whey - Serwatka } \\
\text { Milk - Mleko } 2: 1\end{array}$} & WPC $35-20$ & 4.88 & $23.2 \pm 1.2$ \\
\hline & WPC $35-30$ & 4.84 & $23.9 \pm 0.5$ \\
\hline & WPC $80-20$ & 4.84 & $24.3 \pm 0.9$ \\
\hline & WPC $80-30$ & 4.88 & $26.7 \pm 1.2$ \\
\hline \multirow{4}{*}{$\begin{array}{l}\text { Whey - Serwatka } \\
\text { Milk - Mleko } 1: 1\end{array}$} & WPC $35-20$ & 4.82 & $28.8 \pm 0.8$ \\
\hline & WPC $35-30$ & 4.84 & $30.0 \pm 0.4$ \\
\hline & WPC $80-20$ & 4.87 & $30.0 \pm 0.4$ \\
\hline & WPC $80-30$ & 4.90 & $31.6 \pm 0.0$ \\
\hline
\end{tabular}

It was reported, that beverages with higher milk content were characterised with higher titratable acidity and in case of samples with prebiotic addition, increase of milk content caused lower $\mathrm{pH}$ value. Moreover it was found, that prebiotics had significant $(p=0.05)$ 
influence on $\mathrm{pH}$ level (samples with oligofructose had lower $\mathrm{pH}$ ), while WPC affected significantly $(p=0.05)$ the value of titratable acidity (samples with WPC 80 had higher titratable acidity). Sensorial evaluation showed, that beverages with lower amount of milk (whey : milk $2: 1$ ) had too loose consistency and considerable level of syneresis regardless of used type and concentration of additives. This disadvantages occurred presumably due to too small content of casein, therefore further studies on these beverages were abandoned. Also Castro et al. (2013) reported, that during production of rennet whey-milk fermented beverages, in order to obtain product with satisfactory sensorial properties, the content of milk in the mixture cannot be lower than $50 \%$.

In case of samples with whey : milk ratio $1: 1$, sensorial properties of products with inulin and oligofructose were positively assessed. They had refreshing, typical for whey and fermented milk flavour. The consistency of samples with whey : milk ratio $1: 1$ and prebiotics in both concentrations did not exhibit liquid separation. We can conclude that inulin and oligofructose already in concentration of $2 \%$ were able stabilize the curd structure. Similarly WPC addition stabilized the structure and prevented syneresis occurrence. However, in contrary to samples enriched with prebiotics, WPC had negative impact on sensorial properties and caused deterioration of smell and taste. It can be assumed that the amounts of WPC were too high to be neutral for the flavour. On the other hand, reducing the WPC dose would not provide the stabilizing function, because even at a concentration of $30 \mathrm{~g} / \mathrm{L}$ minimal syneresis was present. Due to the high nutritional values of WPC, the attempts to use them in smaller concentrations in combination with prebiotics were performed (Table 4).

Table 4. Acidity of beverages from whey and milk (1:1) with prebiotics and WPCs Tablela 4. Kwasowość napojów z serwatki i mleka (1:1) z prebiotykami i WPC

\begin{tabular}{|c|c|c|c|}
\hline \multirow{2}{*}{$\begin{array}{l}\text { Added prebiotic } \\
\text { Dodany prebiotyk }[\mathrm{g} / \mathrm{L}]\end{array}$} & \multirow{2}{*}{$\begin{array}{c}\text { Added } \\
\text { Dodany WPC [g/L] }\end{array}$} & \multicolumn{2}{|c|}{ Acidity - Kwasowość } \\
\hline & & $\mathrm{pH}$ & titratable - miareczkowa [ $\left.{ }^{\circ} \mathrm{SH}\right]$ \\
\hline \multirow{4}{*}{$\begin{array}{l}\text { Inulin } \\
\text { Inulina - } 20\end{array}$} & WPC $35-5$ & 5.09 & $22.9 \pm 0.2$ \\
\hline & WPC $35-10$ & 5.09 & $23.7 \pm 0.2$ \\
\hline & WPC $80-5$ & 5.05 & $22.8 \pm 0.0$ \\
\hline & WPC $80-10$ & 5.08 & $24.0 \pm 0.0$ \\
\hline \multirow{4}{*}{$\begin{array}{l}\text { Oligofructose } \\
\text { Oligofruktoza - } 20\end{array}$} & WPC $35-5$ & 4.96 & $23.9 \pm 0.5$ \\
\hline & WPC $35-10$ & 5.01 & $24.5 \pm 0.2$ \\
\hline & WPC $80-5$ & 5.01 & $23.9 \pm 0.5$ \\
\hline & WPC $80-10$ & 5.04 & $24.8 \pm 0.4$ \\
\hline
\end{tabular}

Inulin and oligofructose used in amount of $20 \mathrm{~g} \cdot \mathrm{L}^{-1}$ were combined with 5 or $10 \mathrm{~g} \cdot \mathrm{L}^{-1}$ addition of WPC 35 and WPC 80. It was reported, that variants with oligofructose had significantly $(p=0.05)$ higher values of both titratable and $\mathrm{pH}$ acidity, whereas, as showed statistical analysis, the influence of WPC type was negligible. All of the prepared products had uniform, firm texture and easy to mix, thick consistency. Slightly better consistency had samples with $10 \mathrm{~g} \cdot \mathrm{L}^{-1}$ than with $5 \mathrm{~g} \cdot \mathrm{L}^{-1}$ of both type of WPC. More distinct and sweetish flavour had variants with oligofructose. To compare the influence of WPC type on the flavour characteristics, the samples with WPC 35 were rated definitely higher. This additive in both used concentrations was neutral for the flavour, while WPC 80 caused strange smell and bitter aftertaste. To summarize this part of study, it can be concluded, that good sensory properties can be achieved by combining whey with milk in ratio $1: 1$ and by fortification the mixture with $20 \mathrm{~g} \cdot \mathrm{L}^{-1}$ inulin or oligofructose used alone or together with $10 \mathrm{~g} \cdot \mathrm{L}^{-1}$ of WPC 35 . 


\section{Beverages from whey combined with milk and SMP}

In the subsequent step of the experiment, the simultaneous addition of milk and skimmed milk powder was investigated. SMP was added to the products from whey and milk combined in ratio $1: 1$. The acidity of produced beverages are presented in Table 5.

Table 5. Acidity of beverages from whey and milk with SMP addition

Tabela 5. Kwasowość napojów z serwatki i mleka z dodatkiem odtłuszczonego mleka w proszku (OMP)

\begin{tabular}{lcccc}
\hline \multirow{2}{*}{$\begin{array}{l}\text { SMP addition } \\
\text { Dodatek OMP }\end{array}$} & \multicolumn{4}{c}{ Acidity - Kwasowość } \\
\cline { 2 - 5 }$[\mathrm{g} / \mathrm{L}]$ & \multicolumn{3}{c}{$\mathrm{pH}$} & \multicolumn{2}{c}{ titratable - miareczkowa [ $\left.{ }^{\circ} \mathrm{SH}\right]$} \\
\cline { 2 - 5 } & $\begin{array}{c}\text { after 1 day } \\
\text { po 1 dniu }\end{array}$ & $\begin{array}{c}\text { after 14 days } \\
\text { po 14 dniach }\end{array}$ & $\begin{array}{c}\text { after 1 day } \\
\text { po 1 dniu }\end{array}$ & $\begin{array}{c}\text { after 14 days } \\
\text { po 14 dniach }\end{array}$ \\
\hline 50 & 5.21 & 4.93 & $35.3 \pm 1.2$ & $44.1 \pm 0.6$ \\
100 & 5.26 & 4.87 & $44.8 \pm 1.4$ & $62.3 \pm 0.8$ \\
\hline
\end{tabular}

Variants with greater amount of SMP had higher titratable acidity, what is connected with higher amount of non fat milk solids. Both products had uniform, firm texture and the syneresis did not occurred. It can be concluded, than $50 \mathrm{~g} \cdot \mathrm{L}^{-1}$ addition of SMP is enough to provide high textural quality of the beverages. Moreover in variants with lower SMP addition, the whey flavour was more intensive.

\section{Beverages from whey combined with milk and condensed milk}

The last type of milk considered to use in whey based beverages production was unsweetened condensed milk used alone or together with uncondensed milk (Table 6).

Table 6. Acidity of beverages from whey, milk and condensed milk Tabela 6. Kwasowość napojów z serwatki, mleka i mleka zagęszczonego

\begin{tabular}{lcccc}
\multicolumn{1}{c}{$\begin{array}{c}\text { Whey and milk ratio } \\
\text { Stosunek serwatki do mleka }\end{array}$} & \multicolumn{3}{c}{ Acidity - Kwasowość } \\
\cline { 2 - 5 } & $\begin{array}{c}\text { pH } \\
\text { po 1 dniu }\end{array}$ & $\begin{array}{c}\text { after 14 days } \\
\text { po 14 dniach }\end{array}$ & $\begin{array}{c}\text { after 1 day } \\
\text { po 1 dniu }\end{array}$ & $\begin{array}{c}\text { after 14 days } \\
\text { po 14 dniach }\end{array}$ \\
\hline $\begin{array}{l}\text { Whey : condensed milk } \\
\text { Serwatka : mleko zagęszczone 1 : 1 }\end{array}$ & 5.35 & 5.19 & $33.7 \pm 1.4$ & $40.0 \pm 1.1$ \\
\hline $\begin{array}{l}\text { Whey : condensed milk : milk } \\
\text { Serwatka : mleko zagęszczone : mleko 2: 1:1 }\end{array}$ & 5.24 & 5.02 & $30.1 \pm 0.2$ & $34.8 \pm 0.0$ \\
\hline $\begin{array}{l}\text { Whey : milk } \\
\text { Serwatka : mleko 1: 1 }\end{array}$ & 5.13 & 4.88 & $24.1 \pm 0.2$ & $27.8 \pm 0.3$ \\
\hline
\end{tabular}

Analogously to previous results, the samples from whey combined with condensed milk had the highest level of titratable acidity due to its higher content of milk solids. In case of $\mathrm{pH}$, variants with condensed milk were the less acid, what presumably is a result of buffering capacity of milk proteins. After 2 weeks of storage, increase of both types of acidity was observed. Samples with condensed milk had smooth, creamy and thick consistency and mild, sweetish taste and smell. The whey flavour in samples with whey and condensed milk was less intensive. Condensed milk addition strengthened curd structure and inhibited syneresis. 


\section{The effect of whey pasteurization on the quality of beverages}

One of the crucial steps in fermented beverages production is heat treatment of raw material. Microbial enumeration allowed to reveal, that unprocessed whey is not microbiologically pure enough to be used in the production. Total count of bacteria was in the order of $10^{7} \mathrm{cfu} \cdot \mathrm{mL}^{-1}$. Whey microflora can interference starter culture and fermentation process and lead to deterioration of product quality and durability. Thus the determination of the most appriopriate conditions of whey pasteurization which would significantly improve its microbiological quality without negative impact on suitability for processing, was pivotal step of the study. Three types of treatment conditions were considered: $90^{\circ} \mathrm{C} / 5 \mathrm{~min}, 80^{\circ} \mathrm{C} / 5 \mathrm{~min}$ and $72^{\circ} \mathrm{C} / 10 \mathrm{~min}$. Pasteurization at $90^{\circ} \mathrm{C}$ for $5 \mathrm{~min}$ caused precipitation of proteins and proved to be unsuitable for acid whey. Treatment at $80^{\circ} \mathrm{C}$ for $5 \mathrm{~min}$ and $72^{\circ} \mathrm{C}$ for $10 \mathrm{~min}$ did not deteriorates sensorial quality of whey. These whey underwent microbiological assessment. The total count of bacteria in fresh whey before pasteurization in conditions $72^{\circ} \mathrm{C} / 10 \mathrm{~min}$ and $80^{\circ} \mathrm{C} / 5 \mathrm{~min}$ was respectively $1.13 \times 10^{7}$ and $2.98 \times 10^{7} \mathrm{cfu} \cdot \mathrm{mL}^{-1}$. After treatment, the total count of bacteria was respectively $1.2 \times 10^{1}$ and $4.03 \times 10^{2} \mathrm{cfu} \cdot \mathrm{mL}^{-1}$. Treatment in $72^{\circ} \mathrm{C}$ for 10 min was more effective and caused decrease of total bacteria count for 6 logarithmic cycles, while treatment in $80^{\circ} \mathrm{C}$ for $5 \mathrm{~min}$ for 5 logarithmic cycles. It can be assumed, that lower temperature of $72^{\circ} \mathrm{C}$ was enough to inactivate whey microflora and the main factor deciding about pasteurization effectiveness was its duration.

Conditions of whey heat treatment performed by different scientists are inconsistent. Process of rennet whey pasteurization at similar temperature of $70^{\circ} \mathrm{C}$, though for much longer time of 35 min was conducted in study of Divya and Kumari (2009). The rennet whey was subsequently used for unfermented beverages manufacturing. de Castro et al. (2009) treated rennet whey at temp. of $65^{\circ} \mathrm{C}$ for $30 \mathrm{~min}$ and Pescuma et al. (2008) used $80^{\circ} \mathrm{C}$ also for $30 \mathrm{~min}$. In both quoted works, whey was used for fermented beverages production.

The whey treated in both conditions and unpasteurized whey heated to $80^{\circ} \mathrm{C}$ for about $1 \mathrm{~min}$ were used for beverages production. Whey was combined with milk in a ratio of $1: 1$ and enriched with $20 \mathrm{~g} \cdot \mathrm{L}^{-1}$ oligofructose. In order to have better insight on the influence of heat treatment conditions on product quality, the beverages were storage in refrigeration by 14 days. The acidity after 1 and 14 days of storage are presented in Table 7.

Table 7. Acidity of beverages based on whey pasteurized in different conditions Tabela 7. Kwasowość napojów na bazie serwatki pasteryzowanej w różnych warunkach

\begin{tabular}{lcc}
\hline \multicolumn{1}{c}{$\begin{array}{c}\text { Pasteurization conditions } \\
\text { Warunki pasteryzacji }\end{array}$} & \multicolumn{2}{c}{ Acidity - Kwasowość } \\
\cline { 2 - 3 } \multicolumn{2}{c}{ Results after 1 day of storage - Wyniki po 1 dniu przechowywania } \\
\hline $72^{\circ} \mathrm{C} / 10 \mathrm{~min}$ & 5.11 & $25.6 \pm 0.4$ \\
$80^{\circ} \mathrm{C} / 5 \mathrm{~min}$ & 5.13 & $25.1 \pm 0.2$ \\
Not pasteurized - Niepasteryzowana & 4.93 & $31.2 \pm 1.1$ \\
\hline \multicolumn{2}{r}{ Results after 14 days of storage - Wyniki po 14 dniach przechowywania } \\
\hline $72^{\circ} \mathrm{C} / 10$ min & 4.80 & $29.4 \pm 0.3$ \\
$80^{\circ} \mathrm{C} / 5$ min & 4.90 & $27.2 \pm 0.0$ \\
Not pasteurized - Niepasteryzowana & 4.61 & $40.6 \pm 0.3$ \\
\hline
\end{tabular}


As it was excepted, the acidity of beverages based on unpasteurized whey was distinctly higher than of beverages based on pasteurized raw material what presumably was caused by contribution of whey microflora into fermentation process. The difference increased after 14 days of storage. Comparing the samples obtained from whey treated in different conditions, it can be observed, that the increase in acidity was higher in samples made of whey pasteurized at $72^{\circ} \mathrm{C}$ for $10 \mathrm{~min}$. Concerning the results of sensorial evaluation, it was noted, that beverages from unpasteurized whey were much more sour and thus perceived as worse even after 1 day from production. Nevertheless, variants from pasteurized whey were characterized with more distinct syneresis, what can be connected with higher level of thermal denaturation of whey proteins and consequently their inferior water-binding properties.

The evaluation did not show differences in the quality of products from whey pasteurized in both analyzed conditions $(p=0.05)$. However, heat treatment at $72^{\circ} \mathrm{C}$ for 10 minutes resulted in greater reduction in total count of bacteria than pasteurisation at $80^{\circ} \mathrm{C}$ for $5 \mathrm{~min}$. In addition, it is stated (Sodini et al. 2006), that a lower pasteurization temperature results in lower thermal denaturation of whey proteins and thus their better functional properties. For these reasons the conditions of $72^{\circ} \mathrm{C} / 10$ min were chosen to be performed in the production.

The results allowed to develop the composition and production parameters of fermented beverages based on acid whey. Designed products had sensory properties similar to yogurt popular fermented milk drink. We achieved it due to two factors, that were the usage of yogurt starter bacteria and combining the whey with milk which enriched the mixture with casein and other milk solids. By using only powdered milk, in order to obtain product with desirable sensory properties, $20 \%$ addition was required. Nevertheless, such big amount of SMP suppressed whey's sensory characteristics. Other solution was to mix whey with uncondensed milk. Positively perceived consistency, without syneresis occurrence can be obtained by mixing whey with milk in ratio $1: 1$ and by additional fortification of the mixture with either $20 \mathrm{~g} \cdot \mathrm{L}^{-1}$ of inulin or oligofructose which can be combined with $10 \mathrm{~g} \cdot \mathrm{L}^{-1}$ WPC 35 addition or with $50 \mathrm{~g} \cdot \mathrm{L}^{-1}$ skimmed milk powder. The usage of inulin, oligofructose and WPC 35 ensured additional enhancement of nutritional value of the product. During the study also variants with condensed milk were developed. These were beverages with whey, milk and condensed milk $(2: 1: 1)$ as well as variants containing only whey and condensed milk (1:1). Milk solids content is a crucial factor forming the texture and consistency of milk-type fermented beverages, and in addition it causes shortening of fermentation time. These properties are connected mainly with casein content which possess better textural properties than whey proteins (Damin et al. 2009; Marafon et al. 2011). If the proportion of casein to whey protein in fermented beverages is higher, the consistency is more viscous (Patocka et al. 2006). Combining of whey with different types of milk allows us to state, that increasing of milk content resulted in lower susceptibility to syneresis. The same relation found de Castro et al. (2009) and Castro et al. (2013). It can be explained by the fact, that whey proteins influence the structure of the net formed by casein micelles what leads to more loose and open structure of the curd and higher likelihood of syneresis occurrence (Almeida et al. 2009). The most appropriable conditions of whey pasteurization was treatment at $72^{\circ} \mathrm{C}$ for $10 \mathrm{~min}$. In case of milk heat treatment, we decided to use UHT milk. The production scheme of developed whey based fermented beverages is presented on Fig. 1. 


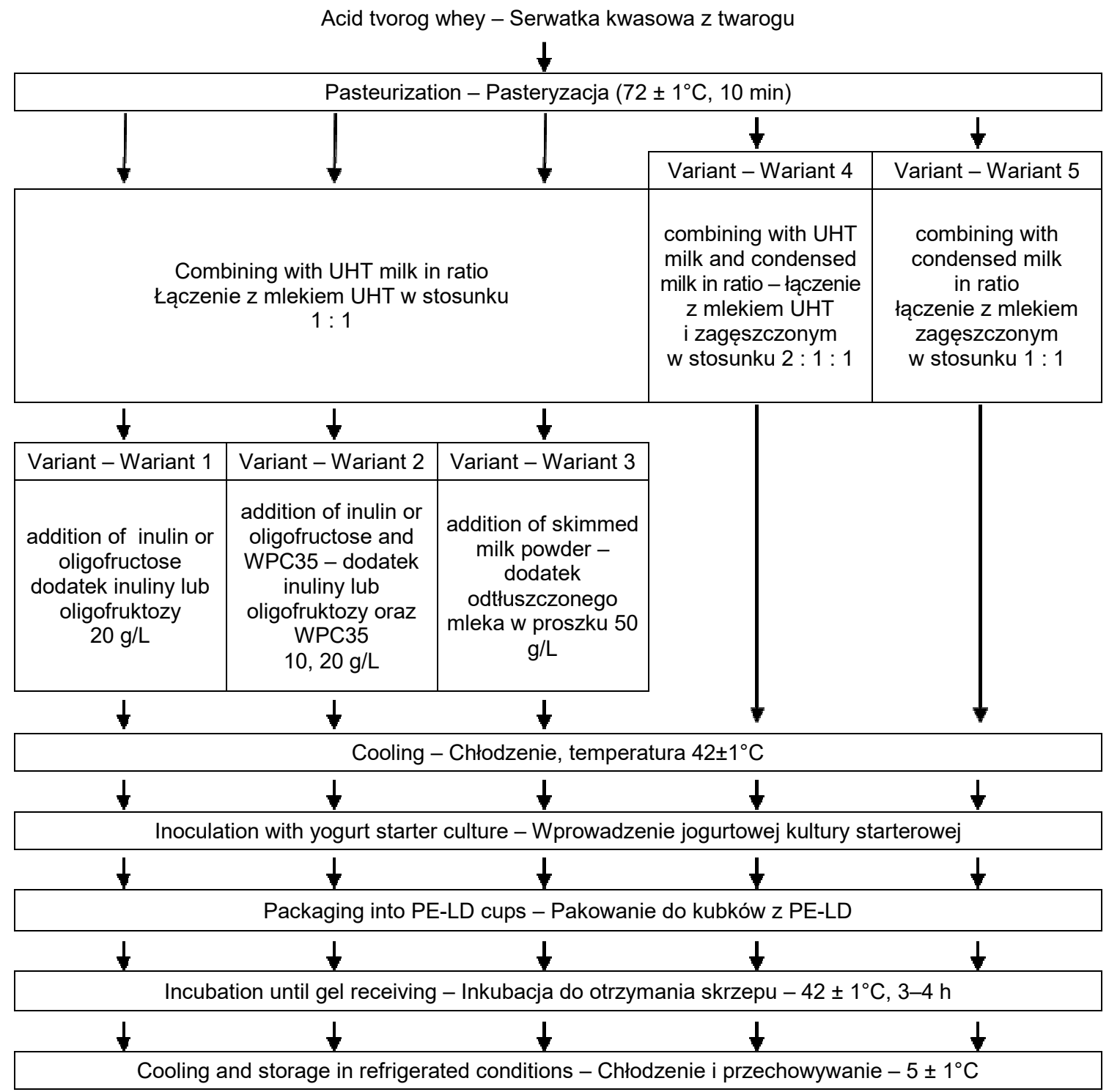

Fig. 1. The production scheme of fermented beverages based on whey Ryc. 1. Schemat produkcji napojów fermentowanych na bazie serwatki

\section{CONCLUSIONS}

The study proved that acid whey manufactured in industrial condition can be used as a raw material to potable fermented milk-type beverages production. To tackle the target it was necessary to combine whey with milk. Moreover the product's characteristics were influenced by type of used milk and by other auxiliary raw materials and additives. The impact of the work comes from the aspect, that whey is use directly after receiving, without such processing steps like concentration, membrane filtration or drying. From this perspective it contributes to limitation of the production costs. The product may be particularly attractive for small producers who are more reluctant to invest in expensive plants for whey processing. Instead of that, they can incorporate the whey into new, high in nutritional value fermented product. The beverages production can be viewed as the new solution of whey utilization, which still remains a challenge for small cheese factories. 


\section{REFERENCES}

Akalin A.S., Gönç S., Ünal G., Fenderya. S. 2007. Effects of fructooligosaccharide and whey protein concentrate on the viability of starter culture in reduced-fat probiotic yogurt during storage. J.F.S. 72(7), M222-M227. DOI: 10.1111/j.1750-3841.2007.00436.x.

Almeida K.E., Tamime A.Y., Oliveira M.N. 2009. Influence of total solids contents of milk whey on the acidifying profile and viability of various lactic acid bacteria. LWT - Food Sci. Technol. 42, 672-678. DOI: 10.1016/j.Iwt.2008.03.013.

Baryłko-Pikielna N., Matuszewska. I. 2009. Sensoryczne badania żywności. Podstawy. Metody. Zastosowania. Kraków, Wydaw. Nauk. PTTŻ. [in Polish]

Bulatović M.L., Krunić T.Z., Vukašinović Skulić M., Zarić B.D., Rakin M.B. 2014. Quality attributes of a fermented whey-based beverage enriched with milk and a probiotic strain. RSC Adv. 4, 55 503-55 510. DOI: 10.1039/C4RA08905G.

Castro F.P. de, Cunha T.M., Ogliari P.J., Teófilo R.F., Ferreira M.M.C., Prudêncio E.S. 2009. Influence of different content of cheese whey and oligofructose on the properties of fermented lactic beverages: Study using response surface methodology. J. Food Sci. Technol. 42, 993-997. DOI: 10.1016/j.Iwt.2008.12.010.

Castro W.F., Cruz A.G., Bisinotto M.S., Guerreiro L.M.R., Faria J.A.F., Bolini H.M.A., Cunha R.L., Deliza R. 2013. Development of probiotic dairy beverages: Rheological properties and application of mathematical models in sensory evaluation. J. Dairy Sci. 96(1), 16-25. DOI: 10.3168/jds.2012-5590.

Chavan R.S., Shraddha R.C., Kumar A., Nalawade T. 2015. Whey based beverage: Its functionality, formulations, health benefits and applications. J. Food Process. Technol. 10(6), 1-8. DOI: 0.4172/ /2157-7110.1000495.

Dajnowiec F., Zander Z. 2013. Współczesne techniki przetwarzania serwatki - przegląd literaturowy [Modern whey processing techniques - literature review]. Prz. Mlecz. 1, 35-37. [in Polish]

Damin M.R., Alcântara M.R., Nunes A.P., Oliveira M.N. 2009. Effects of milk supplementation with skim milk powder, whey protein concentrate and sodium caseinate on acidification kinetics, rheological properties and structure of nonfat stirred yogurt. LWT - Food Sci. Technol. 42, 1744-1750. DOI: 10.1016/j.Iwt.2009.03.019.

Dhamsaniya N.K., Varshney A.K. 2013. Development and evaluation of whey based RTS beverage from ripe banana juice. Food Process. Technol. 4(2), 1000203. DOI: 10.4172/2157-7110.1000203.

Divya S., Kumari A. 2009. Effect of different temperatures, timings and storage periods on the physico-chemical and nutritional characteristics of whey-guava beverage. World J. Dairy Food Sci. 4(2), 118-122.

Food And Agriculture Organization of The United Nations. 2013. Milk and dairy products in human nutrition. Rome, FAO.

Gallardo-Escamilla F.J., Kelly A.L., Delahunty C.M. 2007. Mouthfeel and flavor of fermented whey with added hydrocolloids. Int. Dairy J. 17, 308-315. DOI: 10.1016/j.idairyj.2006.04.009.

Jędrychowski L. 1999. Reduction of the antigenicity of whey proteins by lactic acid fermentation. Food Agric. Immunol. 11(1), 91-99. DOI: 10.1080/09540109999951.

Jeličić I., Božanić R., Tratnik L. 2008. Whey-based beverages - a new generation of dairy products. Mljekarstvo 58(3), 257-274.

Kar T., Misra A.K. 1999. Therapeutic properties of whey used as fermented drink. Rev. Microbiol. 30, 163-169. DOI: 10.1590/S0001-37141999000200015.

Lee W.J. Lucey J.A. 2010. Formation and physical properties of yogurt. Asian-Australas. J. Anim. Sci. 23(9), 1127-1136. DOI: 10.5713/ajas.2010.r.05.

Magalhães K.T., Pereira M.A., Nicolau A., Dragone G., Domingues L., Teixeira J.A., Almeida Silva J.B. de, Schwan R.F. 2010. Production of fermented cheese whey-based beverage using kefir grains as starter culture: Evaluation of morphological and microbial variations. Bioresour. Technol. 101, 8843-8850. DOI: 10.1016/j.biortech.2010.06.083. 
Marafon A.P., Sumi A., Alcântara M.R., Tamime A.Y., Nogueira de Oliveira M. 2011. Optimization of the rheological properties of probiotic yoghurts supplemented with milk proteins. LWT - Food Sci. Technol. 44, 511-519. DOI: 10.1016/j.Iwt.2010.09.005.

Patocka G., Cervenkova R., Narine S., Jelen P. 2006. Rheological behaviour of dairy products as affected by soluble whey protein isolate. Int. Dairy J. 16, 399-405. DOI: 10.1016/j.idairyj.2005.05.010.

Pereira C., Henriques M., Gomes D., Gomez-Zavaglia A., Antoni G. de. 2015. Novel functional whey-based drinks with great potential in the dairy industry. Food Technol. Biotechnol. 53(3), 307-314. DOI: 10.17113/ftb.53.03.15.4043.

Pescuma M., Hébert E.M., Mozzi F., Font de Valdez G. 2008. Whey fermentation by thermophilic lactic acid bacteria: Evolution of carbohydrates and protein content. Food Microbiol. 25, 442-451. DOI: 10.1016/j.fm.2008.01.007.

Pescuma M., Hébert E.M., Mozzi F., Font de Valdez G. 2010. Functional fermented whey-based beverage using lactic acid bacteria. Int. J. Food Microbiol. 141, 73-81. DOI: 10.1016/j.jfoodmicro.2010.04.011.

PN-A-86034 : 1993. Mleko i przetwory mleczarskie. Badania mikrobiologiczne. Ogólne zasady badań. [in Polish]

PN-A-86364 : 1996. Mleko i przetwory mleczne. Serwatka. Metody badań. [in Polish]

PN-EN ISO 8968-1. Mleko. Oznaczanie zawartości azotu. Cz. 1. Metoda Kjeldahla. [in Polish]

PN-ISO 6658 : 1998. Analiza sensoryczna. Metodologia. Wytyczne ogólne. [in Polish]

Sakhale B.K., Pawar V.N., Ranveer R.C. 2012. Studies on the development and storage of whey based RTS beverage from mango cv. Kesar. Food Process. Technol. 3(3), 1000148. DOI: 10.4172/ /2157-7110.1000148.

Sirohi D., Patel S., Choudhary P.L., Sahu C. 2005. Studies on preparation and storage of wheybased mango herbal Pudina (Mentha arvensis) beverage. J. Food Sci. Technol. 42, 157-161.

Sodini I., Montella J., Tong P.S. 2005. Physical properties of yogurt fortified with various commercial whey protein concentrates. J. Sci. Food Agric. 85, 853-859. DOI: 10.1002/jsfa.2037.

Zourari A., Accolas J.P., Desmazeaud M.J. 1992. Metabolism and biochemical characteristics of yogurt bacteria. A review. Le Lait. 72, 1-34. DOI: 10.1051/lait:199211.

Abstract. Acid whey is a valuable raw material obtained during acid-coagulated cheese and acid casein production. Nowadays whey processing techniques are well developed, however the utilization of acid whey, due to low $\mathrm{pH}$, still remains a challenge especially for small dairy plants. The aim of the study was to design and evaluate the fermented beverages based on acid whey containing yogurt bacteria starter cultures. In order to enrich casein content and obtain product with quality characteristics similar to fermented milk drinks, whey was combined with milk, unsweetened condensed milk or skimmed milk powder. Moreover, the beverages were supplemented with prebiotics: inulin and oligofructose and whey protein concentrates. The evaluation of the beverages included acidity measurement and sensorial analysis. Moreover the conditions of whey pasteurization were evaluated. According to the results, the best raw materials and additives were selected. It was stated, that to obtain the product with good sensory characteristics, the addition of milk must amount minimum $50 \%$. The results allowed to invent several kinds of fermented beverages with desirable properties. The most appropriate conditions of whey heat treatment was pasteurization at the temperature of $72^{\circ} \mathrm{C}$ for 10 minutes. The obtained results indicated that acid whey can be considered as a raw material for the production of fermented beverages with acceptable sensory quality. The practical impact of the work comes from the aspect, that it presents the new method of direct utilization of acid whey and it may be a new, attractive alternative for dairy industry. 